\title{
Statement of Provenance
}

THE NEAR EASTERN PICTOGRAPHIC TABLETS, CUNEIFORM TABLETS, AND SEALS

\section{A. Ownership History}

The holdings of pictographic tablets, cuneiform tablets and seals in The Schøyen Collection were collected mainly in the late I980s, with further items in the I990s. They derive from a great variety of former collections and sources. It would not have been possible to collect so many items, of such major textual importance, if it had not been based on the endeavour of some of the greatest collectors in earlier times. Collections that once held tablets, and seals now in The Schøyen Collection are:

Institute of Antiquity and Christianity, Claremont Graduate School, Claremont, California (I970-94)

Erlenmeyer Collection and Foundation, Basel (I943-88)

Cumberland Clark Collection, Bournemouth, UK (I920s-I94I)

Lord Amherst of Hackney, UK (I894-I909)

Crouse Collection, Hong Kong and New England (i920s-80s)

Dring Collection, Surrey, UK (I9II-90)

Rihani Collection, Irbid (ca. 1935) and Amman, Jordan (before 1965-88) and London (I988-)

Lindgren Collection, San Francisco, California (1965-85)

Rosenthal Collection, San Francisco, California (I953-88)

Kevorkian Collection, New York (ca. 1930-59) and Fund (1960-77)

Kohanim Collection, Tehran, Paris and London (1959-85)

Simmonds Collection, UK (1944-87)

Schaeffer Collection, Collège de France, Zürich (I950s)
Henderson Collection, Boston, Massachusetts (I930s-50s)

Pottesman Collection, London (1904-78)

Geuthner Collection, France (ig6os-80s)

Harding Smith Collection, UK (I893-I922)

Rev. Dr.W. F. Williams, Mosul (ca. I850-60)

Frida Hahn Collection, Berlin (I925-73)

Mixon Collection, California and UK

(1920s-1967) and heirs

These collections are the source of almost all the tablets and seals. Other items were acquired through Christie's and Sotheby's, where in a few cases the names of their former owners were not revealed.

The sources of the oldest collections, such as Amherst, Harding Smith, and Cumberland Clark, were antiquities' dealers who acquired tablets and seals in the Near East in the I890s-I930s. During this period many tens of thousands of tablets came on the market: in the summers of 1893-94 alone some 30,000 tablets. While most of these were bought by museums, others were acquired by private collectors. In this way some of the older of these collections were the source of some of the later collections. For instance, a large number of the tablets in the Crouse Collection came from the Cumberland Clark, Kohanim, Amherst, and Simmonds collections. The Claremont tablets came from the Schaeffer Collection, and the Dring tablets came from the Harding Smith Collection.

\section{B. Archaeological Provenance, Findspots}

In most cases the original findspots of tablets that came on the market in the I890s-1930s and later are unknown. Therefore great parts of the holdings of most major museums in Europe and the United States are without archaeological provenance. This 
also applies to The Schøyen Collection. Based on the texts of the tablets themselves the following provenances can nevertheless be identified:

About $85 \%$ of the Early Dynastic and Old Akkadian tablets come from palace and temple archives in Adab and Umma.

About $90 \%$ of the Old Babylonian tablets come from Larsa.

The Old Assyrian tablets all come from Kanesh (Kültepe) excavation level II, mostly from Bedřich Hrozný's findspots 2, 3, 4 and Io, unearthed I890-I925.

All Ugaritic tablets come from Ras Shamra, excavation level I, excavated under the direction of Claude Schaeffer, 1957-58.
Most Neo-Assyrian tablets come from Assur, unearthed during the German excavations under Walter Andrae, I903-I4.

From Lagash and its vicinity there are tablets from the E-Ninnu temple, Ninkar temple in Nimin, Ningishzida temple, Nindara and Ningirsu temples in Girsu, the Ur-Bau temple in Urukug, and the Inanna and Emush temples in Bad-Tibira.

From Nineveh: The Royal Library of Ashurbanipal, and the Ezida temple of Nabu.

From Nimrud: North-west palace of Ashurnasirpal II, the library of Nabû-zuqup-kena, and the palace of Sargon II.

In addition to other major sites like Ur, Uruk, Eridu, Isin, Babylon, Nippur, Susa, Persepolis, there are tablets and seals from at least thirty further sites. 
MANUSCRIPTS IN THE SCHØYEN COLLECTION

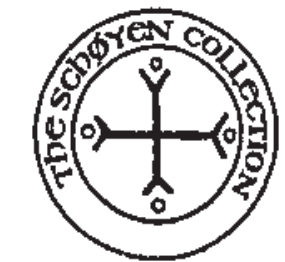

CUNEIFORM TEXTS

Vol. I. Jöran Friberg, A Remarkable Collection of Babylonian Mathematical Texts Sources and Studies in the History of Mathematics and Physical Sciences

New York: Springer, 2007

Vol. II. Bendt Alster, Sumerian Proverbs in the Schoyen Collection

Cornell University Studies in Assyriology and Sumerology 2

Bethesda, Md.: CDL Press, 2007

Vol. III. Stephanie Dalley, Babylonian Tablets from the First Sealand Dynasty in the Schoyen Collection

Cornell University Studies in Assyriology and Sumerology 9

Bethesda, Md.: CDL Press, 2009

Vol. IV.A. R. George, Babylonian Literary Texts in the Schoyen Collection

Cornell University Studies in Assyriology and Sumerology Io

Bethesda, Md.: CDL Press, 2009

Vol. V. Miguel Civil, Lexical Texts in the Schoyen Collection

Cornell University Studies in Assyriology and Sumerology I2

Bethesda, Md.: CDL Press, 2010

Vol. VI. A. R. George, Cuneiform Royal Inscriptions in the Schoyen Collection

with contributions by M. Civil, G. Frame, P. Steinkeller, F. Vallat, K. Volk, M. Weeden, and C. Wilcke

Cornell University Studies in Assyriology and Sumerology I7

Bethesda, Md.: CDL Press, 20I I

Vol. VII.A. R. George, Babylonian Divinatory Texts Chiefly in the Schoyen Collection with an appendix of materials from the papers of W. G. Lambert ${ }^{\dagger}$

Cornell University Studies in Assyriology and Sumerology i 8

Bethesda, Md.: CDL Press, 20I3

Vol. VIII. A. R. George, Mesopotamian Incantations and Related Texts in the Schøyen Collection Cornell University Studies in Assyriology and Sumerology 32

Bethesda, Md.: CDL Press, 2016

Vol. IX. A. R. George, T. Hertel, J. Llop-Raduà, K. Radner, and W. H. van Soldt, Assyrian Archival

Texts in the Schoyen Collection and Other Documents from North Mesopotamia and Syria

Cornell University Studies in Assyriology and Sumerology 34

Bethesda, Md.: CDL Press, 2017

Vol. X. Vitali Bartash, Sumerian Administrative and Legal Documents ca. 2900-2200 BC in the Schoyen Collection Cornell University Studies in Assyriology and Sumerology 35 Bethesda, Md.: CDL Press, 2017

Vol. XI. A. R. George, Old Babylonian Texts in the Schoyen Collection, Part One: Selected Letters

Cornell University Studies in Assyriology and Sumerology 36

Bethesda, Md.: CDL Press, 2018

Vol. XII. Christopher Metcalf, Sumerian Literary Texts in the Schøyen

Collection, Vol. 1: Literary Sources on Old Babylonian Religion

Cornell University Studies in Assyriology and Sumerology 38

University Park: Eisenbrauns, 20I9 
Vol. XIII. Jacob L. Dahl, Ur III Texts in the Schoyen Collection Cornell University Studies in Assyriology and Sumerology 39 University Park: Eisenbrauns, 2020

Vol. XIV.A. R. George and Gabriella Spada, Old Babylonian Texts in the Schoyen Collection, Part Two: School Letters, Model Contracts, and Related Texts Cornell University Studies in Assyriology and Sumerology 43 University Park: Eisenbrauns, 2019

Other volumes are in preparation 